\title{
Intergenerational Class Mobility in Industrial and Post-Industrial Societies: Towards a General Theory
}

\author{
Erzsébet Bukodi \\ Department of Social Policy and Intervention, \\ Nuffield College \\ University of Oxford \\ erzsebet.bukodi@nuffield.ox.ac.uk \\ John H. Goldthorpe \\ Nuffield College \\ University of Oxford \\ John.goldthorpe@nuffield.ox.ac.uk
}

June 2021

Acknowledgements

We are grateful to Fabrizio Bernardi, Bastian Betthäuser, Walter Müller, Brian Nolan, Adam Swift and Nhat An Trinh for their helpful comments on earlier versions of this paper. 


\begin{abstract}
A large body of often rather complex findings on intergenerational social mobility has by now come into existence but theoretical development has not kept pace. In this paper, focusing specifically on class mobility in European nations and the US, we aim, first of all, to identify the main empirical regularities that have emerged from research, making the now standard distinction between absolute and relative mobility. Next, we review existing theories of mobility, which in fact antedate a good deal of this research, and note the main shortcomings that have become evident in these theories, but also elements of them that might still be built upon. We then set out our own theory of intergenerational class mobility and seek to show how it can account for the empirical regularities previously described, while also pointing both to additional evidence that supports it and to ways in which it is open to further empirical test. Finally, we consider some more general implications of the theory and, on this basis, venture some - conditional - predictions on the future of class mobility in more advanced societies. We do not suppose that our theory is in any sense a 'final' one but believe that it improves our understanding of research findings in the field as they currently stand and that further research aimed at its critical evaluation would prove profitable.
\end{abstract}




\section{Introduction}

From the mid-twentieth century, research into intergenerational social mobility has been an area of sustained activity within sociology. Significant progress has been made in relevant conceptualisation, data collection, and methods of data analysis (see e.g. Goldthorpe, 2005; Hout and Diprete, 2006; Torche, 2015). Of late, such research has been given further impetus as a result of social mobility becoming an issue of rising political concern in many countries. However, although a body of empirical findings, impressive in its volume and range, has been created, theory development has not kept pace. That is to say, many of the often rather complex empirical regularities that have been established have not been provided with any very satisfactory explanation. Theories of mobility earlier advanced have become rather evidently inadequate but without being replaced by ones of greater explanatory power.

We seek here to do something to remedy this situation, although with two qualifications. First, we are concerned specifically with intergenerational social mobility treated in terms of class rather than, say, of socioeconomic status or income. Mobility research concerned with longterm trends and with comparisons across national societies has in fact been largely carried out within a class structural context, and largely on the basis of versions of the EGP class schema (Erikson, Goldthorpe and Portocarero, 1979; see also Goldthorpe, 2007, vol.2: ch. 5), or derivatives, in which class is conceptualised in terms of social relations within labour markets and workplaces or, in brief, of employment relations. Second, we focus on the findings of research on intergenerational class mobility from advanced European nations and from the US, since it is in these cases that the highest standards of cross-national comparability have been achieved. This limitation might, however, also prove an advantage. Given comparable data, nations such as Canada, Australia and Japan and also various newly industrialising 
countries could serve as valuable 'out-of-sample' cases against which the theoretical arguments that we advance could be tested.

The structure of our paper is as follows. First, we set out what we take to be the major findings to date in the field of intergenerational class mobility research. This entails a good deal of exposition but is a necessary preliminary. It is important at the outset to identify those findings that present in Merton's words (1987: 2), 'enough of a regularity to require and allow explanation' - that is, explanation via sociological theory - as distinct from findings of place and time specificities that call for explanation of a different, historical kind (cf. Goldthorpe, 2016: ch. 4). Second, we review previous theories of social mobility - these being, however, ones advanced before most of the more complex findings that we would now see as being in need of explanation were produced. We point to the shortcomings that have become apparent in these theories but also aim to identify such elements within them as might still be built upon. Third, we set out our own theory of intergenerational class mobility, drawing in part on earlier work (Goldthorpe, 2007, vol. 2, ch. 7; Bukodi and Goldthorpe, 2021a), and try to show how it can account in a fairly systematic way for the empirical regularities that we have previously noted. Fourth, and in conclusion, we consider some more general implications of the theory and venture some predictions following from it as regards the future of class mobility in more advanced societies.

We do not suppose that what we present is in any way a 'final' theory. Its ultimate fate, like that of all theories, is to be proved insufficient, if not simply wrong. But we believe that it can at all events serve to improve our understanding of research findings as they currently stand, and that future research guided by it - and involving tests of its validity - will represent a profitable way ahead. 


\section{Major research findings}

In considering these findings we treat absolute and relative class mobility separately, following the now standard distinction.

\section{Absolute mobility}

Absolute class mobility refers to the actually observed movement of individuals between different classes. In intergenerational perspective, attention centres on their movement between their family's class, as usually fixed at some point in their adolescence - their class of origin - and their own class, as usually fixed at some point in mid-life or later - their class of destination. The basic measure of absolute mobility is the total mobility rate, as given by the percentage of individuals in a population whose class of destination is different from their class of origin.

A first finding of note is that across industrial and post-industrial societies, total mobility rates would appear to be moving towards a similar and fairly stable level. Using a sevenfold version of the EGP class schema, Erikson and Goldthorpe (1992: Table 6. 3) found that for men born in the first half of the twentieth century in nine European nations total mobility rates ranged from 58 to 76 per cent. On the basis of a collective project and also using EGP7, Breen and Luijkx (2004a: Tables $3.6,3.17)$ presented very similar results for both men and women born 190675 in ten European nations (six being among those covered by Erikson and Goldthorpe) plus Israel. But on the basis of what might be regarded as a follow-up project Breen and Müller report $(2020 b: 256-6,265)$ that, once again using EGP7, in seven European nations plus the US total mobility rates are tending to converge for those born $1955-79$ at around 70 per cent for men and 75 per cent for women. And adopting the sevenfold European Socio-Economic Classification (Rose and Harrison, 2010) - which has the same theoretical basis as the EGP 
schema - Bukodi, Paskov and Nolan (2020: Figs. 1, 3) show that for those born between 1938 and 1985 in 30 European nations, the total mobility rate can be safely placed outside the 7080 per cent range in only one national case for men and one for women. ${ }^{1}$

However, when the total mobility rate is decomposed into upward, downward and horizontal mobility (the latter referring to mobility between classes that, while clearly differentiated, cannot be readily placed in hierarchical order) variation, both cross-national and over time, is far more in evidence, and wider gender differences also arise.

For cohorts of men born in more advanced societies during the first half of the twentieth century, a steady rise in the upward component of total mobility went together with a more or less corresponding fall in the downward component, with little change occurring in horizontal mobility (Erikson and Goldthorpe, 1992: Table 6.3; Breen and Luijkx, 2004a: Table 3.6). This period has then been aptly characterised, so far at least as men are concerned, as 'the Golden Age' of class mobility, when social ascent clearly predominated over social descent. However, for cohorts born in the second half of the century these earlier trends have levelled out or even in some cases reversed. In most West-Central and Southern European nations and also in the US, it is still the case that men experience upward mobility more often than downward, though the difference is tending to narrow. But in most West-Nordic European nations the upward and downward components of the total rate are now close to similarity (Bukodi, Paskov and Nolan, 2020: Fig. 2; cf. Breen and Müller, 2020b: Fig. 11.4) and in a number

\footnotetext{
${ }^{1}$ Greek men fall below this range and French women above it. This study achieved new standards in cross-national comparability in being based on a dataset derived from a single source, the European Social Survey.
} 
of post-Soviet and other post-socialist societies men have become more likely to be downwardly than upwardly mobile. ${ }^{2}$

With women, variation is yet more complex (for Europe, see esp. Bukodi and Paskov, 2020). It would appear that the balance of upward and downward mobility was throughout the twentieth century often less favourable for women than for men. But there is evidence of a general tendency for women, as well as for men, to have experienced more upward than downward mobility in earlier cohorts - i.e. also to have enjoyed a Golden Age of mobility before this tendency, as with men, faded with later cohorts (cf. Breen and Luijkx, 2004a: 617). The main exception, and contrast with men, comes in the case of post-socialist societies where women, unlike men, have continued to experience upward mobility more often than downward, as a result, it would appear, of their being less adversely affected by the decline in heavy industry and the dismantling of state and party bureaucracies.

How, then, are the variations that show up in the components of the total mobility rate to be accounted for? ${ }^{3}$ It is in fact by now well established that what is of primary importance is the class structural context within which mobility occurs. Variation in the balance of upward and downward mobility over time within particular nations very largely derives from the pattern of change in their class structures, and variation across nations from differences in the historical patterns of such change. A direct implication then is that for men, and at least for women

\footnotetext{
2 The grouping of European nations referred to in the text was initially developed by Bukodi and Goldthorpe (forthcoming) as a way of capturing the main pattern of cross-national variation in relative rates of class mobility. See further below and Table 1. However, it turns out also to be of value in differentiating nations in regard to absolute rates.

${ }^{3}$ We intend 'accounted for' at this point in simply a numerical sense rather than implying a theoretically grounded explanation.
} 
working full-time, such variation has little to do with differences in mobility chances for individuals of different class origins - or, that is, with differences in relative rates of class mobility, as discussed below. This point is best brought out through simulation exercises. If a model imposing constant relative rates is embodied in the marginal distributions of a series of mobility tables for the same nation at successive times, or a model imposing common relative rates in the marginals of a series of tables for different nations, the cell values, and thus the upward and downward components of total mobility, that are generated tend to be very close to those actually observed (see e.g. Erikson and Goldthorpe, 1992: Table 6.7; Breen and Luijkx, 2004b: 386-7; Bukodi and Goldthorpe, 2019: p. 67; Bukodi, Paskov and Nolan, 2020: Fig. 10).

Following from this, the Golden Age of class mobility can then be seen as resulting in very large part from changes in class structures that occurred as societies moved through industrialisation into post-industrialism. A steady expansion of the managerial and professional salariat went together with a decline of the agricultural classes of peasants, small farmers and farm workers and then of the general body of manual wage-workers (cf. Breen and Luijkx, 2004b: 383-5; Breen and Müller, 2020b: 251-5, 277-9). Class structures were, in other words, upgraded, with progressively 'more room at the top'. Consequently, increased upward mobility into more advantaged classes could occur without any requirement for greater downward mobility on the part of individuals originating in these classes. Class mobility, considered in absolute terms, was a positive-sum game.

Conversely, the ending of the Golden Age came about as in the late twentieth century in most advanced societies the growth of the managerial and professional salariat tended to slacken off, albeit in cross-nationally differing degrees and with some gender variation. As a consequence of its earlier growth, however, a higher proportion of children of salariat origins 
existed than previously who were exposed to the possibility of demotion, while at the same time the continuing decline of less advantaged classes meant that the pool of those in a position to move up was reduced. Thus, the larger numbers at risk of downward mobility and the smaller numbers potentially upwardly mobile made it possible for the downward component of the total mobility rate to increase and the upward component to decrease without any change being entailed in relative mobility chances (cf. the discussion in terms of class floor and ceiling effects in Breen and Müller, 2020b: 257-8). In other words, change occurred - although in cross-nationally differing degree - in the components of the total mobility rate not because of changes in rates of upward and downward mobility relative to different class origins but rather in the shape of the class structures within which these rates operated.

In regard to absolute rates, therefore, the issue, referred to in the Introduction, clearly arises of the scope for sociological theory that actually exists. How far is it possible to demonstrate regularities in such rates that are sufficient to 'require and allow' sociological explanation - as distinct from features specific to particular national societies or groups of societies that call for explanation by reference to their distinctive economic, sociocultural and sociopolitical histories? This is an issue to which we will need to return.

\section{Relative mobility}

Relative class mobility refers to the chances of individuals of different class origins being found in different class destinations when considered net of class structural change; or, that is, to the strength of the inherent association between class origins and destinations. Were no association to be present, a state of 'perfect' mobility - or complete social fluidity - would exist: individuals' chances of ending up in a particular class destination would be independent 
of their class origins. Conversely, the stronger the association, the more unequal are relative mobility chances and the lower is social fluidity within the class structure. Relative mobility rates can be expressed in terms of odds ratios, and the degree of relative mobility, or fluidity, within class structures is now usually measured through the application of loglinear and logmultiplicative models based on odds ratios.

Results of research into relative rates of class mobility might appear less consistent than those of research into absolute mobility. A notable feature is the way in which there have been shifts back and forth between studies emphasising temporal stability and cross-national commonality in these rates and those emphasising both over-time and cross-national variation.

Early work was influenced by the analyses of mobility of Featherman, Jones and Hauser (1975), undertaken on the basis not of class but of the socioeconomic status of occupational groupings. Anticipating in effect the distinction between absolute and relative rates, these authors argued, using current American and Australian data for men, that the 'endogenous mobility regimes' of these nations showed a large measure of both stability and commonality, even though their actually observed mobility rates varied widely due to 'exogenous', structural factors. And they boldly suggested that a comparable situation would be found across all societies with market economies and nuclear family systems. Grusky and Hauser (1984) then followed up the 'FJH hypothesis' with analyses of class mobility - though distinguishing only 'white-collar', 'blue-collar' and farm classes. Drawing on tables relating to men born in the first third of the twentieth century in 16 nations, they reported 'substantial' cross-national similarities in levels of social fluidity, though also noting some variations of sociological interest 
that were at least as strongly associated with political regimes as with level of economic development.

However, a very different set of findings was presented by Ganzeboom, Luijkx and Treiman (1989) who re-coded to a six-class version of the EGP schema data from 149 mobility tables from 35 nations covering men born from the late nineteenth- to the mid-twentieth century. What their analyses revealed, they claimed, was that while the pattern of relative rates showed a basic cross-national similarity, there was significant cross-national variation in the level of social fluidity, but going together with a general trend towards increasing fluidity: i.e. relative rates were, cross-nationally, becoming steadily more equal. These findings were, however, quickly challenged on grounds mainly of data quality and model choice (e.g. Jones, 1992; Wong, 1994), and a reversion back to something closer to earlier views then came with Erikson and Goldthorpe (1992), who further contested the Ganzeboom, Luijkx and Treiman results (1992: 99-101).

In all, Erikson and Goldthorpe studied relative rates of class mobility in twelve European societies plus the US, Australia and Japan, again drawing on mobility tables for men born in the first half of the twentieth century. ${ }^{4}$ They sought to refine the FJH hypothesis by postulating not a common pattern of social fluidity across all advanced societies but rather a 'core' pattern to which all such societies approximated but on which a degree of variation could occur. They further proposed a 'topological' model (Hauser, 1978; Hout, 1983a) of this core pattern comprising the effects of class hierarchy, class inheritance and sector and also of various

\footnotetext{
${ }^{4}$ In contrast to Ganzeboom, Luijkx and Treiman, Erikson and Goldthorpe re-coded their national mobility data to EGP7 at unit-record level in the interests of achieving a higher standard of crossnational comparability.
} 
'affinity' or 'disaffinity' effects capturing particular mobility linkages or discontinuities between classes. In discussing national deviations from their model, Erikson and Goldthorpe found these to be mostly ones 'of a highly specific, historically formed character' (1992: 175) but insofar as any more general factors were involved, they placed main emphasis on the extent to which under different political regimes state power was used to modify inequalities of condition and opportunity alike. Among the European cases they studied, the highest levels of fluidity, though on differing patterns, were shown by the state socialist societies of Czechoslovakia, Hungary and Poland, together with social-democratic Sweden. ${ }^{5}$

As regards change in relative rates within societies, Erikson and Goldthorpe, working on the basis of quasi-cohorts - i.e. age groups distinguished within national samples - found no evidence of a general tendency towards greater fluidity. Rather, relative rates showed a high degree of stability and such changes as were in evidence were not in any consistent direction. For a limited number of their national cases, Erikson and Goldthorpe were also able to study the class mobility of women and again found relative rates to be largely constant over time.

Continuing research has then led to further twists in the story. The collective project directed by Breen (2004) largely followed the approach of Erikson and Goldthorpe but for the eleven nations covered drew on more extensive data and brought coverage forward to men and women born up around 1970. The findings chiefly differed from those of Erikson and Goldthorpe (Breen and Luijkx, 2004b: Table 15.1) in that evidence of increasing social fluidity

\footnotetext{
${ }^{5}$ Australia, Japan and the US also figured among the relatively more fluid nations but in the latter case this was so only on when using data with evident problems of comparability. In the light of 'corrections' made to allow for these problems, the US would appear (Erikson and Goldthorpe, 1985) to have a level of fluidity similar to that of England, towards the middle of the European range.
} 
was found for men in five nations (and possibly in three others) ${ }^{6}$ and for women in six. However, from the follow-up study of, as previously noted, seven European societies and the US (Breen and Müller, 2020a), which is based on analyses of true birth cohorts ranging from the early twentieth century through to the mid-1970s, a more qualified conclusion emerges. Consistently with earlier findings, increasing fluidity is revealed in most nations among both men and women born before the 1950s but for those born later this increase does not in general continue (Breen and Müller, 2020b: 289-90). And, broadly in line with this, Bukodi, Paskov and Nolan (2020: 19-21 and Appendix A), in their study of 30 European societies, find no evidence of increasing fluidity across quasi-cohorts of men born between 1938 and 1975 .

From this latter study, two other findings of note emerge. First, it is shown that across postsocialist societies - which were not represented in the Breen-Müller project - social fluidity is in fact tending to decrease, consistently with the results of research into class mobility carried out in the earlier years of post-socialism (for Russia, see Gerber and Hout, 2004 and for an extensive comparative study, Jackson and Evans, 2017).

Second, it is found (see also Bukodi and Paskov, 2020, and Bukodi and Goldthorpe, 2021a) that for both men and women variation in levels of social fluidity across European nations can be better understood not as entirely continuous but rather as differing between two sets of relatively high and low fluidity nations, each comprising three different geopolitically defined groups, as shown in Table 1. In the high fluidity set, post-Soviet nations and one group of other post-socialist nations can be placed, at least for the time being, together with a group of WestNordic nations, while in the low fluidity set a contiguous group of West-Central nations and a

\footnotetext{
${ }^{6}$ These were cases where results from comparative analyses undertaken by Breen and Luijkx differed from those reported by the author(s) of the national studies.
} 
group of Southern nations are joined by a second group of post-socialist nations. Included in this latter group - along with Bulgaria - are Hungary and Poland. That is to say, these nations which, under state socialism, were found by Erikson and Goldthorpe (and cf., also, Breen and Luijkx, 2004a: Fig. 3.3) to be among the most fluid in Europe now appear at the opposite end of the European range.

Finally, in further work (Bukodi and Goldthorpe, 2021b), the application of a new version of Erikson and Goldthorpe's (1992) topological model brings out the same 'primary' factors (Lieberson, 1987) of class hierarchy, class inheritance and status affinity as the source of inequalities in relative mobility chances across all the groups of nations in Table 1. But two 'secondary' factors, creating group variation in both the level and the pattern of these inequalities, are also identified. One is gender and the other, of greater consequence and confirming Erikson and Goldthorpe's earlier finding, is the degree of state involvement in social mobility processes.

\section{*** TABLE $1 * * *$}

How, then, can these findings on relative rates of class mobility, that may at first sight appear unduly diverse, be brought together? We would suggest that two rather clear and significant empirical regularities do in fact emerge. First, so far as more advanced Western societies are concerned, relative rates did show some quite common, if not universal, tendency to become more equal over the years following World War II. That is, during les trentes glorieuses (Craft and Toniolo, 2012) of rapid economic growth, low unemployment, rising real incomes and living standards and - crucially, as we will later argue - during the Golden Age of absolute mobility when upward rates steadily increased. But this tendency, where it occurred, was not sustained as the 'long boom' came to an end in the mid-1970s. The rising equality of 
opportunity that had benefited those born before the mid-century petered out for those born later. Second, so far as Eastern European societies are concerned, these also saw an increase in social fluidity after World War II, though in this case one associated far more with political than economic developments: that is, with the establishment of state socialist regimes committed to using their power to radically reshape the life chances of different social classes. But here too a check or indeed reversal of the previous trend occurred with the collapse of these regimes in 1989-90 and with the transitions that subsequently took place to versions of capitalist democracy.

\section{Previous theories of social mobility}

We here review previous theories of social mobility, although quite selectively. We focus on their authors' treatment of intergenerational class mobility, and on the explanations they propose of the regularities that they see in such mobility.

\section{Sorokin}

Sorokin (1927/1959) was writing before any nationally-based studies of social mobility had been undertaken. He draws on a wide range of historical and enthnographical material, and also on such sociological studies as were available of mobility in particular communities and industries and of the recruitment of various occupational groups and elites. He was also of course writing before the distinction between absolute and relative rates of mobility was established, and although at various points he can be taken as implicitly making such a distinction, he has in general to be understood as being concerned with total mobility as resulting from both structural effects and the operation of endogenous mobility regimes. 
Sorokin believed that modern western societies were characterised by relatively high rates of social mobility and that in these societies levels of mobility had probably been rising since the end of the eighteenth century. But at the same time he rejected the idea that a new form of human society had emerged in which there would be a 'perpetual increase of mobility'. In a long-term historical perspective, periods of increasing mobility were regularly followed by ones in which mobility declined: there was no definite overall trend, merely 'trendless fluctuation'. In the modern period, many former juridical and religious obstacles to mobility had been removed, but others had, potentially at least, been created (1927/1959: 153). Educational institutions were now major agencies of social selection, acting as 'sieves' that served to test, select and distribute individuals into different class positions, and - contrary to what was widely supposed - mobility could in this way be restricted as much as promoted. This was so because 'universal education and instruction leads not so much to an obliteration of mental and social differences as to their increase'. The school, if it performs its task properly, is a 'machinery' for the stratification of society, not for its levelling (1927/1959: 189-90). Also with regard to the expansion of higher education, Sorokin noted the possibility - already, he thought, being realised in the US - that mobility achievable through education could be limited as a result of what would now be called 'over-qualification': that is, by the supply of university graduates outstripping the growth of occupational opportunities 'proper to the degree'. All that would result in intensified competition among graduates for what they would regard as suitable employment. (1927/59: 201).

It might then be questioned in what sense, if any, Sorokin did put forward a theory of social mobility, at least as regards the causes of its levels, patterns and trends - comparable to his bold and very general theory of its consequences: that is, of its damaging 'dissociative' effects on individuals' communal participation and psychological well-being (1927/59: Part VI). He can 
be read as implying that mobility levels, patterns and trends are the outcome of particular and often complex contingencies, and are thus not open to any theoretical, as opposed to specific historical, explanation. There is, though, one respect in which Sorokin, consistently with his idea of 'trendless fluctuation', does move towards a general proposition of some interest: that is, in suggesting that as regards the equality or inequality of mobility chances there are limits that cannot be exceeded (1927/1959: 57-60, 141-3). No society has come close to having a form of stratification in which mobility is effectively precluded; but neither has any society come close to a situation of perfect mobility, in which no association exists between the positions of parents and children. In human society, at any level of development, various factors will always come into play to maintain these two limits, and will operate with increasing force as they are approximated.

Lipset and Zetterberg

Lipset and Zetterberg $(1956,1959)$ were writing at a time when the results of the first national surveys of social mobility, made after World War II, had become available, although still before the distinction between absolute and relative rates was explicitly recognised. While they did note in passing (1959: 27, emphases in original) that 'There may be more mobility in one country than in another, and yet less equality of opportunity', they in fact followed Sorokin in focussing on total mobility - but then arrived at a quite different position.

For Lipset and Zetterberg (see esp. 1959: 37-8, 57-60) modern, industrial societies were distinctive in their high rates of social mobility, and in particular of class mobility, and this was not to be seen as simply a phase in a long-term historical process of trendless fluctuation in mobility levels. Rather, it marked a step change. In the course of industrialisation, the occupational and class structures of societies had been fundamentally transformed and, under 
industrialism, change in these structures had to be seen as built-in and continuous. Thus, the probability of children ending up in the same class positions as their parents would always be at a relatively low level, and with, it was implied, upward mobility being more likely than downward.

Consistently with this line of argument, Lipset and Zetterberg were then led to the further claim (1959: 13, 48-56) that all societies at a similar level of industrial development would have similar levels and similar patterns of class mobility. In this regard, the course of structural change was determinative. Differences in national cultures and value systems had, they held, little effect on mobility, and they therefore questioned all claims of national 'exceptionalism', including that of the US as being an outstanding 'land of opportunity'.

It was, however, in regard to the issue of cross-national variation in mobility that Lipset and Zetterberg's position met with criticism from an early stage (e.g. Miller, 1960; Jones, 1969) and, in the light of subsequent research, has in fact to be regarded as most obviously inadequate (see e.g. Erikson and Goldthorpe, 1992: 189-204, 375-6). While some broad crossnational commonalities can be seen in long-term changes in occupational and class structures, such changes have often proceeded - and continue to proceed - on differing patterns and at differing tempi according to the specific trajectories of industrialism and post-industrialism that societies have followed. As a result, and as was earlier noted, while there is evidence of convergence in total rates of class mobility, there is clear evidence too of structurally created variation in component rates over time and place - and possibly entailing a rise in downward rather than upward mobility.

Finally, it is relevant to note that in addition to claiming generally operative structural factors on levels and patterns of mobility, Lipset and Zetterberg also emphasised the importance 
(1956: 163, 1959: 60-3) of generally operative motivational factors - located 'in the realm of more or less universal ego-needs'. Drawing heavily on Veblen (1934), they saw any social stratification order as being in itself a source of mobility motivations. Thus, they maintained, while people sought to protect their class positions in order to protect their egos, they sought still more urgently to improve their class positions as a means of enhancing their egos. Even under the most rigid forms of stratification, such as the Indian caste system, there was 'a constant striving for upward mobility' and, under industrialism, structurally created opportunities heightened such striving through significantly raising the chances of its success.

The liberal theory

The liberal theory of social mobility - an element of more general 'modernisation' theory emerged in American sociology in the 1970s under a variety of influences, including the analyses of economic growth of Clark (1957), Rostow (1960) and Kuznets (1966), the work of Kerr et al. (1960) on 'the logic of industrialism', Parsons' functionalist analysis of modern societies (1960), and the major empirical study of Blau and Duncan (1967) of status attainment. In the period in question, the theory was in fact quite widely subscribed to but its fullest and most coherent statements are to be found in Treiman (1970) and, with a more specific reference to class mobility, in Bell $(1972,1973)$.

Proponents of the liberal theory fully agreed with Lipset and Zetterberg that industrial - and likewise post-industrial - societies were characterised by distinctively high rates of social mobility, and by a preponderance of upward over downward movement as a result of the progressive upgrading of occupational and class structures, driven by economic growth. However, in contrast with Lipset and Zetterberg, their focus was not on such structurally induced mobility but rather on issues of equality of mobility chances - or, that is, on what was 
becoming understood as relative mobility. And in this regard they gave central importance to a matter in which Lipset and Zetterberg, unlike Sorokin, showed surprisingly little interest: that of the role played in actual processes of social mobility by education. The liberal theory can in fact be most clearly expressed in terms of the associations existing between individuals' class origins, their education, and their eventual class destinations - or of associations within what subsequently became known as the 'OED triangle'. However, in contrast to Sorokin, liberal theorists held that in industrial and still more in post-industrial societies, changes occur in these associations on a pattern that means that increasing fluidity is created within their class structures, so that in this way too, as well as through structural effects, class mobility is forced on to a steadily rising trend.

In the case of the association between individuals' class origins and their educational attainment - the OE association - the argument was that this progressively weakens or, in other words, equality of educational opportunity increases. The rapid rate of technological and organisational change in modern societies means that there is a steadily growing demand for more highly qualified and trained personnel, who have 'theoretical' rather than simply 'empirical' knowledge (Bell, 1973: 14, 18-26 and ch. 3). This gives rise, at a societal level, to a functional requirement for educational expansion and also for the 'democratisation' of educational institutions so as to increase their openness to individuals of all social origins alike. Human resources cannot be wasted: talent must be exploited wherever in society it is to be found. Correspondingly, then, as the $\mathrm{OE}$ association weakens, the association between individuals' education and their class destinations - the ED association - strengthens. Employing organisations, in order to maintain their own efficient functioning, have to recruit individuals to different positions increasingly on the basis of their 'educated talent' (Bell, 1972: 30-1) and without reference to their social backgrounds. Criteria of achievement prevail over 
those of ascription. And, finally, the association between individuals' class origins and their class destinations that is not mediated via education - the 'direct' OD association - itself weakens because insofar as the advantages or disadvantages of social origins are not expressed via educational attainment, they are of declining importance for individuals' experience of mobility or immobility (Bell, 1973: 410).

What was, in short, implied was that the outcome of the economic and societal changes set in train in the western world by industrialisation, and maintained under its liberal democracies, led, as a matter of functional necessity, to what could be described as an education-based meritocracy. ${ }^{7}$ Post-industrial society, Bell claimed (1972: 30) is 'in its logic' such a meritocracy. In the course of a 'worldwide secular trend', the mobility chances of individuals of different social origins would become equalised, subject only to any limits that might be set by the social distribution, whether genetically or socio-culturally determined, of educational potential. ${ }^{8}$

The liberal theory represents by far the most ambitious attempt thus far made to provide a general explanation of levels and trends of class mobility in modern societies and of the processes through which these levels and trends are produced. It is therefore of particular

\footnotetext{
${ }^{7}$ As regards the state socialist societies of Central and Eastern Europe, proponents of the liberal theory generally held to some version of the 'convergence' thesis. They believed that functional exigencies would mean that in these societies any attempts at 'ideologically' based social selection - as, say, in favour of individuals from peasant or worker backgrounds or with appropriate political credentials would sooner or later have to give way to selection by merit as educationally defined.

8 The phrase 'worldwide secular trend' comes from the paper by Ganzeboom, Luijkx and Treiman (1989), previously cited, which aimed in effect to give comprehensive empirical support to the liberal theory. It was estimated that this trend towards greater social fluidity entailed a decrease of 1 per cent per annum in the overall OD association, so that its continuation would mean that by the early twentyfirst century many societies would be coming close - contra Sorokin - to a state of perfect mobility.
} 
importance to examine in some detail the extent to which, and the ways in which, the theory has proved inadequate.

The most obvious difficulty for the theory arises with the empirical findings previously described, which indicate that class mobility rates are no longer moving on the lines that the theory would predict. Total absolute rates would appear to have stabilised, and it is now downward rather than upward mobility that, in a number of societies, tends to be on the increase. Yet more serious, though, given the main focus of the liberal theory, are the findings concerning relative rates. The increasing equality in such rates that did show up in quite a number of western nations for men and women born in the first half of the twentieth century has not been maintained for those born later. The idea of some inherent tendency towards greater social fluidity within modern societies is called into evident doubt. ${ }^{9}$

One may then go on to ask where did the theory specifically go wrong - that is, as regards the changes that were supposed in the associations existing within the OED triangle that would lead to a steady rise in social fluidity.

As regards the OE association, some shifts have occurred in the weight of the evidence against or in favour of the liberal theory. To focus on the major contributions, the collection of papers edited by Shavit and Blossfeld (1993), covering thirteen industrial nations over the course of the twentieth century, led to the conclusion that the association between individuals' social origins, whether treated in terms of social class or socioeconomic status, and their levels of educational attainment had in most cases remained remarkably constant. Only in the two cases

\footnotetext{
${ }^{9}$ It is also relevant to note that for the national cases of increasing social fluidity that were demonstrated in the Breen (2004a) collection, no 'unambiguous' link could be established with their level of economic development (Breen and Luijkx, 2004b: 397-8).
} 
of the Netherlands and Sweden was a weakening apparent. But, more supportive of the liberal theory, Breen et al. $(2009,2010)$, drawing on larger samples from the populations of eight European nations, were able to detect some general tendency for the association between class origins and educational attainment to be reduced. Broadly consistent findings were then reported for the eight nations covered in the Breen and Müller (2020a) collection for cohorts born up to the mid-twentieth century. However, for later cohorts what was found was that for women the OE association remained largely constant, while for men it remained constant or in five of the eight cases - the Netherlands and Sweden along with Germany, Switzerland and the US - actually strengthened (Breen and Müller, 2020b: 289, and see Figures 11.17 and 11.18). Even if it is accepted that over some large part of the twentieth century the $O E$ association did tend to weaken, as expected under the liberal theory, it can then obviously be questioned whether this trend is a continuing one.

Turning next to the ED association, relevant research is more restricted but its results are far less equivocal. Very little, if any, evidence has been produced of this association strengthening over time, as the liberal theory would envisage, except in the case of socialist nations. In fact, with five out of six western nations represented in the Breen (2004a) collection for which evidence was available the finding was that during the later twentieth century the ED association actually tended to weaken - (West) Germany being the one exception (Breen and Luijkx, 2004b: 393; and cf. Breen and Müller, 2020b: 286-7). In other words, no grounds here exist for supposing the development of an education-based meritocracy - and with the implication that, even if some reduction were achieved in class-linked inequalities in educational attainment, this would not necessarily translate into a corresponding reduction in inequalities in class mobility chances. 
Finally, in the case of the direct OD association, the available empirical evidence again goes contrary to the liberal theory. For example, in the British case studies using different methodologies (Breen and Karlson, 2014; Kuha, Bukodi and Goldthorpe, forthcoming) have reached the same conclusion that no more than half of the association between class origins and destinations is mediated by education and that the direct association of origins and destinations appears quite stable. And more extensive results on trends come from the comparative project reported on in Bernardi and Ballarino (2016), covering eleven European societies plus Israel, Japan and the US. In only two of these nations - the Netherlands and Sweden - was the direct OD association (DESO) found to be weakening, in ten it was constant over time, and in two - France and Israel - actually strengthening (Ballarino and Bernardi, 2016a: 259-61 and Table 16.1). ${ }^{10}$

What is then chiefly apparent is that the role of education in creating greater fluidity within the class structures of modern societies has proved to be a good deal more problematic than the liberal theorists envisaged. They were right in anticipating that, under economic and social pressures, attempts at reforming educational institutions in the interests of a greater equality of opportunity would be made and that educational systems would significantly expand. But it would appear that they failed adequately to recognise the possibilities that the effectiveness of such egalitarian reforms might have its limits; that following on educational expansion, the class returns to education need not be maintained; and that the direct effects of class origins on class destinations could be persistent.

10 In the analyses reported, social origins and destinations were primarily treated in terms of socioeconomic status rather than class but further analyses based on class - using the EGP schema were in most cases undertaken and gave essentially similar results (Bernardi and Ballarino, 2016b: 12). More detailed analyses of DESO are provided for Britain by Gugushvili, Bukodi and Goldthorpe (2017) and for Spain by Bernardi and Gil-Hernández (2020). 


\section{Elements of a general theory}

As previously observed, attempts at developing sociological theory are appropriate only in relation to the explanation of well-established empirical regularities. In the case of intergenerational class mobility, the question then arises of where the focus of theoretical endeavour should lie. In this regard, we are in a better position than earlier theorists in view of the now generally accepted and applied distinction between absolute and relative rates.

We believe that it is in fact on levels, patterns and trends in relative rates that theoretical attention has to centre. Absolute rates are predominantly determined by the course followed by class structural change, and wide and largely contingent variation is in this regard apparent across the histories of particular national societies. While the transitions from agricultural to industrial, and then from industrial to post-industrial, societies do grosso modo carry consequences for the evolution of class structures, these have evidently worked out, under particular national economic and socio-political circumstances, in significantly different ways (see e.g. Singelmann, 1978). With relative rates, in contrast, levels, patterns and trends, do show a sufficient degree of constancy and commonality or of variation of a more systematic kind to warrant theoretical interest. This does not, however, mean that consideration of absolute rates is irrelevant to our theoretical concerns. Such rates and the class structural changes underlying them will in fact figure as important context for the social processes through which we would see relative rates as being generated.

As noted, the liberal theory was one of implicit, if not explicit, functionalist inspiration. The movement towards an education-based meritocracy was explained as a response to the functional exigencies of societies characterised in course of their economic development by rapid technological and organisational change. But a problematic feature of functionalist 
theories is their weak micro-foundations. They tend to lack adequate accounts of how the exigencies that are postulated are actually met at the level of individual action. We advance a theory of intergenerational class mobility that is grounded in such action and, moreover, in action that can be regarded as rational in at least a subjective sense and that is in turn intelligible.

We present the elements of our theory in relation to what we would see as three major explanatory issues arising from the research findings that we have reviewed, and especially as these findings run contrary to expectations under the liberal theory. We also refer to reported research findings of our own - chiefly pertaining to Britain and to Hungary - and to those of others that would appear consistent with our theory. But it obviously remains open to far more extensive and direct empirical test, as also do certain more general implications of the theory and related - conditional - predictions with which we conclude.

Why in industrial and post-industrial societies have relative rates of class mobility not shown the 'worldwide secular trend' in the direction of greater equality that would be expected under the liberal theory?

While it is possible with some nations to identify periods over the last hundred years or so in which fluidity within their class structures has increased, trends in this direction have been neither universal nor continuous. In more recent times such trends have in many national cases been checked and in post-socialist societies have actually been reversed. In other words, the endogenous class mobility regimes of modern societies show some evident resistance to change in the direction of a greater equality of mobility chances.

We would see this resistance to change as deriving primarily from the motivation and the capacity of families holding more advantaged class positions to protect their children from 
downward mobility. Any equalisation of relative rates of mobility - any weakening of the net association between class origins and destinations - must imply that the increasing upward mobility that ensues is directly matched by increasing downward mobility. But it is the latter that is, so to speak, the sticking point. Lipset and Zetterberg emphasised motivations to achieve upward mobility. In contrast, we would emphasise motivations to avoid downward mobility.

Sorokin's theory of the negative, 'dissociative' effects of mobility, whether upward or downward, has been increasingly called into question by subsequent research. It is now apparent that at least in the case of social class, it is downward mobility that has the more damaging consequences, and not only in economic terms but also as regards social participation (see e.g. Chan, 2018) and psychological and indeed physical well-being (see e.g. Präg and Richards, 2019; Präg and Gugushvili, 2020). Parents do therefore have good objective grounds for seeking to prevent the downward mobility of their children. But, in addition, we would suggest, their motivation is in this regard intensified by a now well-documented subjective factor, that of 'loss aversion'. What the theory of loss aversion claims (Kahneman, 2011: chs. 26, 27) is that losses subjectively 'loom larger' than gains even if of the same objective value, and that the motivation to avoid losses is thus stronger than that to achieve gains. Given, then, that parents who hold more advantaged class positions - in, say, the managerial and professional salariat - do have such intensified motivation to ensure that their children are not less advantaged than themselves, they can be expected to attach high priority to pursuing this end in the deployment of their resources. These will include their superior economic resources - relatively high and secure incomes rising over the life-course - which derive directly from their class positions (Bukodi and Goldthorpe, 2019: ch. 1) and also, insofar as a correlation exists between class, social status and education, their superior sociocultural 
and specifically educational resources. ${ }^{11}$ At the higher levels of the class structure the motivation to prevent the downward mobility of children and the capacity to do so can thus be seen as coming together in a powerful combination. We do not need or wish to imply a lack of motivation to achieve upward mobility on the part of families in less advantaged class positions - as might result, say, from a 'poverty of aspirations'. Our claim is only that this motivation tends to be less strong than that to avoid downward mobility and, in the nature of the case, is not backed up by the same resources. The asymmetry that here arises is crucial. It is, we propose, the basic source of the resistance to change that endogenous class mobility regimes display. ${ }^{12}$ On this, our central theoretical argument, it is then possible to elaborate in regard to the two further questions that arise.

Why has the resistance to change of endogenous mobility regimes not been progressively overcome through educational expansion and reform and the growing importance of educational qualifications in determining class positions - i.e. through the steady weakening of the OE association and strengthening of the ED association - as envisaged in the liberal theory?

Research into the OE and ED associations has thus far led to a situation that is not easily interpretable. As noted, while the OE association did in many societies weaken somewhat over

\footnotetext{
${ }^{11}$ In previous research (Bukodi and Goldthorpe, 2013; Bukodi, Erikson and Goldthorpe, 2014; Bukodi, Goldthorpe and Zhao, 2021) we have been concerned to stress that the correlations in question are only moderate and that in relation to children's educational attainment, parental class, status and education have to be regarded as having independent and in part cumulative effects. In the present context, however, it is the fact that positive correlations do exist that is important.

12 Others, we would note, have of late taken up a somewhat similar position to ours. In particular, Bernardi and his associates have documented systematic 'class compensation effects' in educational careers, stemming from parents' concerns to ward off any threat of the downward mobility of their children (Bernardi, 2014; Bernardi and Cebolla-Boado, 2014; and see also Grätz and Wiborg, 2020). And subsequently, in the Spanish case, similar compensation effects have been shown (Bernardi and GilHernández, 2020) to extend into the labour market in regard to children whose educational careers remained less successful than might have been hoped for.
} 
the decades after World War II, as the liberal theory would predict, this weakening has not in general been sustained - and in some instances is now being reversed. And, further, contrary to the liberal theory, the ED association has not consistently strengthened but has, if anything, more often weakened.

In the research in question educational attainment has been conceptualised and measured in absolute terms: that is, by number of years completed or level of qualifications gained. We would propose, and consistently, as will be seen, with our general theoretical position, that a better understanding of change in the OE and ED associations can be obtained if educational attainment is conceptualised and measured in relative terms. The crucial distinction to be made here is that between education as a consumption good and as an investment good. If education is regarded as a consumption good, it can be treated as an absolute good in the sense that the value of its consumption to any one person is not affected by the extent of its consumption by others. However, if education is regarded as an investment good, as it evidently is when its association with individuals' class destinations is at issue, it is more appropriately treated as a relative, or following Hirsch (1976), a 'positional' good. In this case, the value of an individual's level of educational attainment will be dependent on the levels of attainment of others. What matters is not how much education individuals have in absolute terms but how much relative to others, and especially relative to those others with whom they will be in most direct labour market competition. Insofar, then, as educational attainment is being taken as a mediator of class mobility, and in particular in the context of the educational expansion that has characterised modern societies, the case for a relative measure - as, say, in terms of individuals' quantile positions within the overall educational distribution for their birth cohort - would appear a powerful one. 
With education being measured relatively, what we would then expect is that, at least in capitalist free-market economies, the OE and ED associations will not show any secular tendency to weaken or strengthen. Thus, in the British case, in research covering three birth cohorts spanning a quarter of a century, we have found (Bukodi and Goldthorpe, 2016) that while both associations do more or less continuously weaken when education is treated in absolute terms, when education is treated in relative terms, the weakening of the $\mathrm{OE}$ association becomes statistically insignificant and change in the strength of the ED association is directionless. Our position does of course call for much wider empirical testing. ${ }^{13}$ But what we would at this stage further note is that there are grounds for supposing that a relative rather than an absolute view of education is that taken by employers in their recruitment procedures and also by parents and their children insofar as they consider education as an investment rather than a consumption good.

As regards employers, we would follow the lead of those economists who argue that the labour market is not simply one in which individuals with different levels of human capital compete with each other over wages but also one in which they compete over jobs, understood as training opportunities that offer differing lifetime earnings prospects. In the underlying model, employers rank potential employees on the basis of their qualifications - also seen as signals of their trainability and productivity if engaged - so as to form a 'labour queue', and this they seek to match to the positions they have to fill, their 'job queue', working from the top downwards. In other words, it is the relative aspect of individuals' qualifications that count.

\footnotetext{
${ }^{13}$ As regards the OE association, Triventi et al. (2016) show for Italy that, over the period they cover, this weakens whether education is treated in absolute or relative terms - indicating that taking the latter view does not entail a finding of no change, as has sometimes been suggested. We are not aware of further relevant research in the case of the ED association.
} 
And the strength of the ED association will then vary with the degree of correspondence between the two queues as this is affected by fluctuations in supply and demand. ${ }^{14}$

With the economic futures of their children in mind, parents, we would then suggest, are led to view qualifications in the same relative way as do employers. In particular, advantaged parents with the motivation to protect their children against the risks of downward mobility will respond to any threats posed by educational expansion and reform by taking appropriate 'defensive measures' (Thurow, 1976, 1983). In what becomes in effect an educational arms race, they will use their superior resources in order to ensure that their children retain their competitive edge so far as educational success and levels of qualification are concerned - i.e. retain their positions in the labour queue - and by seeking quality as well as simply quantity of education (Lucas, 2001). Strategies will vary with the features of different national educational systems. Resort to the private educational sector may be a favoured option or, within the state sector, residential shifts into the high-value catchment areas of high-performing schools, and the buying of additional support from private tutors. ${ }^{15}$ Through such 'commodification of opportunity', made possible by emerging 'opportunity markets' (Grusky, 2016; Grusky, Hall and Markus, 2019) and intensified in many societies by rising inequalities in income and wealth, parents with greater economic resources can gain increasing educational advantage for their children that then carry through to the tertiary level. And, in addition, there is evidence of the growing importance in creating such advantage of parents' socio-cultural and specifically educational, as well as economic, resources - as, for example, in providing a favourable home-

14 The relevance of labour market 'job competition' and signalling theories to issues of education and social mobility is discussed at greater length in Goldthorpe (2014).

15 See further for Britain Bukodi and Goldthorpe (2019: ch. 4) and for the US, Reeves (2017) and Markovitz (2019, ch. 5). 
learning environment and informed guidance on progressing through the educational system. ${ }^{16}$ In these ways, then, powerful countervailing tendencies can be formed against any weakening of the $\mathrm{OE}$ association that may be sought through educational expansion and reform, and the strength of this association may even be increased.

Why in industrial and post-industrial societies has there been no consistent weakening in the direct association between class origins and destinations - that not mediated via education as would be expected if the development of an education-based meritocracy were in train?

Education has become a major agency of social selection in modern societies, and thus plays an important role in mediating the association between social origins and destinations. But this role has never become the quite dominant one that Sorokin and the liberal theorists envisaged, and there is little indication that it is increasing over time. The direct effect of social origins DESO - appears remarkably persistent. Speaking of a direct effect here means of course direct only in relation to education, and the questions obviously arise not only of the consequences of DESO but also of how, if not through education, the effect of origins on destinations comes about.

The operation of DESO is not necessarily less favourable to social fluidity than the mediation of the OD association via education. Whether it is or not is an empirical question. However, we would see DESO as in fact working against social fluidity in serving to create both 'glass ceilings'

16 For example, Dotti Sani and Treas (2016) report for eleven advanced societies a positive association between parents' educational level and 'child-care time', and that this association is tending to strengthen overtime. In recent research in which we have ourselves been involved there are repeated indications that the importance of parents' educational level for their children's educational attainment is increasing relative to that of their class or income. See e.g. Bukodi, Erikson and Goldthorpe (2014); Bukodi, Bourne and Betthäuser (2017); Bukodi, Goldthorpe and Zhao (2021) 
that limit individuals' opportunities for upward mobility, and 'glass floors' that limit their risks of downward mobility - although, consistently with our main line of argument, with the latter being the more important. In research based on a British birth cohort, it has been shown (Gugushvili, Bukodi and Goldthorpe, 2017: Fig. 8.1) that men of less advantaged social origins who hold higher secondary or tertiary educational qualifications at labour market entry still have lower chances of obtaining a managerial or professional class position than their counterparts from more advantaged origins. But such social origin effects are yet more marked in the case of men with no, or only sub-secondary, qualifications. In this latter case, it turns out that those of the most advantaged social origins still have, despite their educational shortcomings, around a 45 per cent chance of eventually accessing the managerial and professional salariat, as against only a 15 per cent chance of ending up in the wage-earning working class, while the corresponding chances for men of the least advantaged origins are 20 per cent and over 50 per cent. Cross-national findings that likewise show DESO as being the more important, the lower individuals' levels of education are reported by Ballarino and Bernardi (2016: Table 16.2).

Research into the actual mechanisms through which DESO operates is, unfortunately, neither extensive nor highly revealing. Most attention has centred on the possibility of more advantaged parents being able to further their children's labour market prospects through social contacts and influence - and in this way compensate for any deficiencies in their educational attainment. But empirical support for this possibility is not all that strong. Rather few respondents to surveys acknowledge receiving such parental help and, more importantly, there is little evidence that those who do have benefited from it as regards their occupational careers (for results from British research, see Bukodi and Goldthorpe, 2019: 163-5). The main 
exception is where children are taken into employment in family businesses, which are then likely at some stage to be passed over to them. In such intergenerational succession, education would appear to play relatively little role (Ishida, Müller and Ridge, 1995).

We would ourselves attach most general importance to the extent to which DESO is related to the concern to avoid social descent, and is expressed through what Girod (1970) labelled as 'counter-mobility'. That is, upward mobility achieved by individuals in the course of their working lives that offsets initial downward mobility at labour market entry - as resulting, say, from educational failings - and that brings them back to the social level of their families of origin. Counter-mobility remains a not uncommon 'class trajectory' in modern societies and especially where credentialist limits on the possibilities of worklife mobility are not strong (for Britain, see Bukodi et al., 2016). What is then suggested is that even if the motivation to avoid downward mobility should prove in some way ineffective in the context of individuals' education, it may still persist into their working lives and lead to counter-mobility. Possibilities for such compensatory career advancement may be particularly favourable in the services sectors of modern economies, where formal qualifications may matter less than personal and life-style attributes associated with more advantaged class origins (cf. Jackson, Goldthorpe and Mills, 2005; Bernardi and Gil-Hernández, 2020).

However, what is perhaps in this connection of yet greater consequence is a process that, while perhaps appearing as DESO, is not so - or only if education is taken as ending at labour market entry (as it has been in a good deal of research on educational inequalities). What we refer to is counter-mobility that is mediated via further education over the course of working life. Provision for such adult education has been typically seen as offering second chances to those who, because of their disadvantaged social origins, have been previously unable to realise their 
full academic potential. But, at least for Britain, where adult education is extensive, it can be shown (Bukodi, 2017) that the second educational chances that are most strongly associated with subsequent upward mobility - that is, ones that lead to new academic rather than vocational qualifications - are in fact taken up largely by men and women of relatively advantaged social origins. Ability to meet the opportunity and other costs involved would seem of obvious relevance here. But further, one of the best predictors of an individual obtaining an additional academic qualification in the course of working life is that at labour market entry they were in a less advantaged class position than that of their parents (Bukodi, 2017: Table 4). In this case, the persistence of the motivation to avoid downward mobility is very clearly in evidence, and at the same time education strikingly appears not as 'the great equaliser' but rather as serving to maintain the stability of the endogenous mobility regime.

\section{More general implications of the theory}

We have maintained that what primarily prevents any sustained movement towards greater fluidity within class structures is the motivation and the capacity of families in more advantaged class positions to protect their children against the possibility of downward mobility. What would then follow is that where and when a greater equality in relative mobility chances has in fact come about, some weakening has occurred in the expression of this motivation and/or capacity. There are grounds for believing that this is in fact the case.

As regards parental motivation, the context provided by absolute class mobility rates becomes of main importance. During the Golden Age of class mobility in the decades after World War II, the growth of the managerial and professional salariat was such that increasing upward 
mobility could occur without this reducing the chances of intergenerational immobility of those born into the higher levels of the class structure. As previously remarked, class mobility was a positive-sum game. Although we may suppose that among more advantaged parents the motivation to protect their children's favoured position in relation to educational attainment and labour market opportunities was indeed present, there was no great need for - and in fact little indication of - this motivation leading to any very specific reaction to changing circumstances. Thus, in the period in question, widely introduced educational reforms, such as free secondary education for all, increases in the school leaving age, moves towards comprehensive rather than selective secondary schooling, and the expansion of tertiary education, do not appear to have provoked much in the way of 'defensive measures'.

However, the situation that has arisen in many societies from the later twentieth century onwards is a very different one. As earlier noted, with the reduced rate of growth of the managerial and professional salariat, but with more men and women starting out from more advantaged class positions, the predominance of upward over downward mobility has declined and class mobility has increasingly become a zero-sum game. Moreover, the greater numbers experiencing downward mobility could be taken as creating a disturbing 'demonstration effect'. In such a situation, the motivation to protect their children's prospects among families at the higher levels of the class structure can be expected to strengthen as loss aversion is activated. Further educational reforms aimed at equalising opportunity will not be passively accepted by parents whose children's own life-chances could appear to be adversely affected. They will apply their resources in all forms to strategies of the kind earlier referred to, aimed at preserving their children's relative advantage within the educational system and the labour market. And it is in this regard also notable that over recent years educational policy, and 
especially in regard to tertiary education, has in most advanced societies become characterised by widening partisan divisions, turning on questions of equality of opportunity and the extent of public subsidisation of educational careers, in which divergent class interest are readily apparent (Ansell, 2010; Jungblut, 2016).

In short, from the position we adopt it is in no way accidental that the period in which, at least for some western societies, there is evidence of an equalisation of educational opportunity and of relative class mobility chances should largely coincide with the structurally induced Golden Age of generally beneficent levels and patterns of absolute class mobility. Nor is it accidental that with the ending of the Golden Age these equalising tendencies, where they had existed, have for the most part been halted.

As regards parental capacity to protect children against downward mobility, it is the experience of socialist and post-socialist nations that is of prime relevance. Although some amount of cross-national variation has to be recognised, what can in general be said is that under state socialism not only were economic inequalities of condition greatly reduced, including through the abolition of most private property in production, but efforts were also directly made to reduce inequalities of opportunity. In the interests of 'class justice', educational systems were expanded and reformed in ways directly intended to be beneficial to the children of peasants and workers, while forms of 'negative discrimination' against the children of previously more advantaged classes were, at least for a time, set in place. Further, with a command economy, it was possible for close linkages to be established across all sectors between levels of educational qualification and levels of employment.

Where it was possible for comparisons to be made with the pre-socialist era, as, for example, for Hungary, it was found that over the early decades of socialist rule, the association between 
class origins and educational attainment weakened (Simkus, 1981; Simkus and Andorka, 1982) and that between educational attainment and class destinations strengthened, while both the direct and the overall origins-destinations associations also weakened (Andorka, 1990; Bukodi and Goldthorpe, 2010). ${ }^{17}$ And, as earlier noted, cross-national comparisons then regularly revealed that state socialist societies had greater fluidity within their class structures than did most western liberal democracies.

What is thus indicated is that under state socialism the capacity of parents to use at least their economic resources to influence the educational and the labour market careers of their children became more limited, and in particular as regards the intergenerational maintenance of more advantaged class positions. This is not to say that the association between the class positions of parents and their children disappeared. Downward mobility was not of the extent that would have occurred had perfect mobility prevailed. Despite economic levelling, differences that remained in families' sociocultural and educational resources were sufficient to prevent this. Nonetheless, some movement was brought about towards a form of education-based meritocracy, albeit rather different from that which liberal theorists envisaged for the western world. ${ }^{18}$

\footnotetext{
${ }^{17}$ Hungary is the best documented case (and see also Szelényi, 1998) but the less extensive evidence available for other socialist societies points in much the same direction. See for Czechoslovakia, Boguszak (1990), for Estonia, Saar (2010) and for other regions within the USSR, Titma, Tooma and Roosma (2003). Poland was somewhat deviant in that agriculture was not collectivised and small independent businesses were more widely permitted than elsewhere. Under socialism, increasing fluidity was more apparent for women than for men (Mach, 2004).

${ }^{18}$ The idea of meritocracy under socialism has been questioned on the grounds that access to many higher level managerial and administrative positions was politically controlled and that children of the nomenklatura gained special educational and other privileges. However, the first point would seem much stronger in some cases, notably East Germany (see Solga, 2006), than in others, and the numerical importance of the second, at a population level, was not large (Titma, Tuma and Roosma, 2006).
} 
This new social order did not, however, survive the break-up of the Soviet bloc and the transition of former socialist societies to versions of capitalist democracy. Again as earlier noted, the subsequent tendency has been for relative rates of class mobility to become more unequal and in some cases, such as Hungary and Poland, to an extreme degree within the European range. On the one hand, economic inequality has increased as a result of rising earnings returns to education, the growth of self-employment and of privately owned businesses, and the dismantling of egalitarian social policies. On the other hand, state educational systems have been re-stratified and private education has substantially expanded, leading to widening inequalities in educational attainment. And as employers have been able to introduce their own personnel policies, the importance in accessing higher-level class positions of factors other than education - such as social background and 'connections' would appear to have grown (see for the Czech republic, Mateju, Rehakova and Simonova, 2003; for Hungary Bukodi and Róbert, 2011, Keller and Róbert, 2016; for Poland, Baranowska, 2008; for Russia, Gerber, 2018; and for the former East Germany after reunification, Betthäuser, 2019).

In other words, greater differences in parental resources have come together with greater opportunities for more advantaged parents to use their resources to protect their children's life chances. While the motivation to act in this way may have weakened somewhat under socialism, on account of social mobility having become a 'low stakes game' at least in economic terms, what is important is that once the restraints of socialism were removed, such motivation 
was strengthened and, more importantly, became backed by a far greater capacity than before to achieve the intergenerational class stability that was sought. ${ }^{19}$

What then follows from the theory we have outlined for the future of class mobility in advanced societies? Any predictions have to be conditional - in particular, conditional on the absence of quite transformative social changes, such as at the present time might be envisaged in consequence of global economic collapses, pandemics or environmental disasters. With this being recognised, we would start out from the proposition - with a nod back to Sorokin - that for all societies with a capitalist market economy, a liberal democratic polity and some version of a nuclear family system, a limit exists to the extent to which relative rates of class mobility can be brought towards equality, and one that will only be approximated with increasing sociopolitical difficulty. This is in effect a limit on the extent to which more advantaged families can actually be prevented from using their superior resources to prevent the downward mobility of their children.

We are not able to specify where the limit that we hypothesise actually lies. In the light of the experience of the state socialist societies of the post-war years, we can say that it would appear possible to go some way beyond this limit, given economic and educational systems largely under the control of an authoritarian political regime. But the important question that arises concerns the more advanced societies of the present day: how do they stand in relation to this limit? In the interests of further exposing our theoretical position to test, we venture a

\footnotetext{
${ }^{19}$ It is of some significance that in Hungary this became to some extent the case before the collapse of state socialism: that is, with the introduction of the New Economic Mechanism in 1968 and of further measures of 'marketisation' in 1979-81, which allowed more scope for private enterprise and led to widening economic inequality (Bukodi and Goldthorpe, 2010).
} 
response on the following lines, with reference to the groups of European nations in Table 1 plus the US. Figure 1 provides a graphical summary of our response.

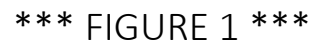

In the case of the Southern European nations that fall within the low fluidity set, we would believe that they are still some way from the limit, and that the possibility of a further increase in fluidity is a realistic one. That is, if only through their continuing economic development hastening the decline of agricultural classes and of small family concerns and thus reducing propensities for intergenerational immobility. In addition, though, given the marked degree of inequality in educational opportunity that still exists and the strong association between low educational attainment and disadvantaged class positions, continuing educational reforms of a relatively basic kind would have the potential to raise fluidity. And such reforms would be unlikely to appear as a threat to, nor thus to lead to countervailing action from, more advantaged classes, especially since in these nations, as a result of the pattern of class structural change, upward mobility remains, for the time being, a more common experience than downward.

Also within the low fluidity set are the more economically advanced nations of the West Central group. In their case too we see some possibility for the achievement of greater fluidity, though with the reduction of educational inequalities here being the crucial requirement. If educational reforms can bring about such a reduction, then the importance of formal qualifications in the labour markets of these nations - the high degree of credentialism that 
prevails - makes it likely that a greater equality in mobility chances will in turn result. ${ }^{20}$ But in contrast with the Southern nations, the reforms required would be of more than a basic kind: the 'easy' gains in this regard have already been made. Further-reaching and more politically demanding measures would be called for, aimed in the first place at a significant reduction in the existing degree of stratification of educational systems at the secondary level. However, as earlier noted, for three nations in this group for which recent findings are available - Germany, the Netherlands and Switzerland - the indication is that the OE association is in fact now strengthening. In other words, within this group, the creation of greater fluidity via educational policy would appear to be faced with contrary tendencies, the sources of which so far remain unclear.

Turning next to the three groups of post-socialist societies that figure in Table 1 , in the case of the group falling in the low fluidity set, comprising Hungary and Poland and also Bulgaria, we have no reason to envisage any change in this situation for the foreseeable future. But with the two groups in the high fluidity set, comprising those formerly in the USSR and the remaining post-socialist nations, we would expect this to be only a temporary allocation - one associated with relatively turbulent transition periods and/or less rapid institutional change and 'marketisation'. In the light of the evidence previously referred to of decreasing fluidity in these nations, and of the factors driving this tendency, our prediction here would be that over the next decades they will fall back clearly below our notional limit and quite possibly follow Hungary, Poland and Bulgaria into the low fluidity set.

\footnotetext{
${ }^{20}$ As a notable example, Betthäuser (2017) shows that in Germany a raising of the school leaving age led to some equalisation in educational attainment and in class mobility chances - whereas in Britain, with a clearly lower level of credentialism, Sturgis and Buscha (2015) find that it led to the former but not to the latter.
} 
Finally, the remaining group in the high fluidity set, the West Nordic group, comprising the four Nordic nations plus France, Ireland and the UK, is that most critical for us. It is these European nations that we would regard as coming closest to the limit on increasing fluidity that we envisage. In Britain (Buscha and Sturgis, 2017; Bukodi and Goldthorpe, 2019: ch. 3) and Ireland (Layte and Whelan, 2004, Whelan and Layte, 2006) equalisation in mobility chances has been rather slight, if evident at all, over now many decades. In at least some of the Nordic nations previous equalisation has in more recent times evidently stalled (for Finland, see Erola, 2009; for Sweden, Breen and Jonsson, 2020). And in France, though equalisation has continued, this has been at a decreasing rate (Vallet, 2014: 15; 2020: 109). We would further be inclined to place the US in the same situation as these European nations, despite some inconsistency in findings on trends in relative rates (see e.g. Mitnik, Cumberworth and Grusky, 2016; Hertl and Pfeffer, 2020) and the lack of extensive US-European comparative studies. There would at all events appear to be agreement that any increase in fluidity within the American class structure that may have occurred up to the mid-twentieth century has over more recent decades fallen away (and cf. Hout, 2018 on relative mobility in terms of socioeconomic status). Moreover, Long and Ferrie (2013) confirm the conclusion earlier reached by Erikson and Goldthorpe (1985) that over the course of the twentieth century British and American relative rates of class mobility became very similar.

As regards these nations that we see as approximating our hypothetical limit, it is not our claim that no further increase in fluidity is possible. It is, rather, that if such an increase is to be achieved, it will have to be through some relatively large-scale political mobilisation in favour of far more radical public policy interventions than have thus far been made. In the nations in question, not only have the gains in fluidity that follow from the decline of the agricultural and 
other more traditional economic sectors now been largely realised but also those deriving from the expansion and the at least formal de-stratification and democratisation of educational systems. Further measures aimed at equalising relative mobility rates will then need to be ones that are very specifically directed towards restricting the capacity of more advantaged families to use their superior resources in order to exploit the various possibilities that still remain for them to enhance the educational and employment chances of their children, and thus help ensure intergenerational class stability. Such measures may, however, be expected to meet with strong socio-political resistance, and especially insofar as a context now often exists in which, because of class structural effects, downward mobility is in any event becoming more widely experienced.

To revert to our underlying thesis, given a capitalist market economy, wide inequalities across classes in at least economic resources will always be present, and are as likely to widen as to contract. And, given a liberal democratic polity, the extent to which it is possible to prevent parents from using the resources they possess, economic and otherwise, in order to 'do the best they can' for their children is subject to evident contestation and, ultimately, constraint. Thus, as regards education, policies aimed at discouraging resort to the private sector by, say, increasing its cost through taxation, or compelling schools and universities to have more socially balanced intakes, are open to powerful opposition on the grounds of involving improper state intervention and the curtailment of the rights of individuals and, in some cases, of independent institutions. ${ }^{21}$

${ }^{21}$ For example, in Britain proposals that private schools should lose their charitable status and associated tax relief, or that entry to state secondary schools should be by lot or based on banded ability, or that elite universities should be required to take contextual factors into account in their admissions procedures, have all been attacked from the political right as inadmissible 'social 
Moreover, it has to be recognised that powerful forces in any event exist creating inequalities in educational attainment, and in turn in mobility chances, that lie largely beyond political reach. That is, in the capacity of socioculturally and educationally advantaged families to engage in what Lareau (2003) has aptly called the 'concerted cultivation' of children, aimed at the fullest possible expression of their academic and more general human potential - perhaps in some degree independent of, but still entirely consistent with, a concern to protect them against the risk of déclassement. The important point here is that the activities involved - from bedtime stories and supper table debates to the direct encouragement of, and help with, academic progress and personal development - have all to be regarded as being constituent of family life (Swift, 2004; Brighouse and Swift, 2014). And thus to seek in some way to restrict these activities, even if it were possible, could scarcely be regarded as desirable.

In sum, even if all measures were to be taken that could be thought politically feasible in a liberal democracy by way of increasing equality of opportunity, in the context of the inequalities of condition inherent in a capitalist market economy, the family would remain as the ultimate source of the resistance to change that the endogenous mobility regime presents - and of the limit on such change, in the direction of more equal mobility chances, that we have proposed.

engineering'. And, perhaps more significantly, they have not in all cases received unequivocal support from the political left. The proposal by Grusky, Hall and Markus (2019) that leading American universities should admit students who win 'within-tranche' entry competitions, with tranches being defined by parental income levels, seems seriously to neglect the likely extent of politically-backed resistance that would arise both from universities and from parents who benefit from the status quo. 
Table and Figure 
TABLE 1: Nations and national groups in high and low fluidity sets

\begin{tabular}{llllll}
\hline & \multicolumn{2}{c}{ High fluidity set } & & \multicolumn{2}{c}{ Low fluidity set } \\
Post-Soviet & Post-Socialist-1 & West-Nordic & West-Central & Southern & Post-Socialist-2 \\
\hline Estonia & Czech Republic & Denmark & Austria & Cyprus & Bulgaria \\
Lithuania & Romania & Finland & Belgium & Greece & Hungary \\
Latvia & Slovakia & France & Switzerland & Italy & Poland \\
Russia & Slovenia & Ireland & Germany & Portugal & \\
Ukraine & & Norway & Luxembourg & Spain & \\
& & Sweden & Netherlands & & \\
& & United Kingdom & & & \\
\hline
\end{tabular}


FIGURE 1: Fluidity trajectories in relation to proposed limit for countries with a capitalist market economy, a nuclear family system and a liberal democratic polity ${ }^{(a)}$



Note (a):

main trajectory

- - - $\quad$ alternative trajectory 


\section{References}

Andorka, Rudolf. 1990. "Half a Century of Trends in Social Mobility in Hungary". In Social Reproduction in Eastern and Western Europe, edited by Julian Peschar. Nijmegen: Institute for Applied Social Science.

Ansell, Ben. 2010. From the Ballot to the Blackboard. Cambridge: Cambridge University Press.

Ballarino, Gabriele and Fabrizio Bernardi. 2016. "The Intergenerational Transmission of Inequality and Education in Fourteen Countries: A Comparison." In Education, Occupation and Social Origin, edited by Fabrizio Bernardi and Gabriele Ballarino. Cheltenham: Edward Elgar.

Baranowska, Anna. 2008. "Poland." In Europe Enlarged, edited by Irene Kogan et al. Bristol: Policy Press.

Bell, Daniel. 1972. "On Meritocracy and Inequality". The Public Interest, 29: 29-68.

Bell, Daniel. 1973. The Coming of Post-Industrial Society. New York: Basic Books.

Bernardi, Fabrizio 2014. "Compensatory Advantage as a Mechanism of Educational Inequality: A Regression Discontinuity Based on Month of Birth". Sociology of Education 87(2):74-88

Bernardi, Fabrizio and Héctor Cebolla-Boado. 2014. "Previous School Results and Social Background: Compensation and Imperfect Information in Educational Transitions". European Sociological Review, 30: 207-17.

Bernardi, Fabrizio and Gabriele Ballarino eds. 2016a. Education, Occupation and Social Origin. Cheltenham: Edward Elgar.

Bernardi, Fabrizio and Gabriele Ballarino. 2016b. "Education as the Great Equalizer: A Theoretical Framework". In Education, Occupation and Social Origin, edited by Fabrizio Bernardi and Gabriele Ballarino. Cheltenham: Edward Elgar.

Bernardi, Fabrizio and Carlos Gil-Hernández. 2020. “The Social-Origins Gap in Labour Market Outcomes: Compensatory and Boosting Advantages Using a Micro-Class Approach". European Sociological Review, doi: 10.1093/esr/jcaa034.

Betthäuser, Bastian. 2017. "Fostering Equality of Opportunity? Compulsory Schooling Reform and Social Mobility in Germany". European Sociological Review, 33: 633-44.

Betthäuser, Bastian. 2019. "The Effect of the Post-Socialist Transition on Inequality of Educational Opportunity: Evidence from German Reunification". European Sociological Review, 35: 461-73.

Blau, Peter and Dudley Duncan. 1967. The American Occupational Structure. New York: Free Press.

Boguszak, Marek. 1990. "Transition to Socialism and Intergenerational Class Mobility". In Class Structure in Europe, edited by Max Haller. Armonk, NY: Sharpe.

Breen, Richard ed. 2004. Social Mobility in Europe. Oxford: Oxford University Press.

Breen, Richard. 2010. "Educational Expansion and Social Mobility in the $20^{\text {th }}$ Century". Social Forces, 82: 365-88. 
Breen, Richard and Ruud Luijkx. 2004a. "Social Mobility in Europe between 1970 and 2000". In Social Mobility in Europe, edited by Richard Breen. Oxford: Oxford University Press.

Breen, Richard and Ruud Luijkx. 2004b. "Conclusions." In Social Mobility in Europe, edited by Richard Breen. Oxford: Oxford University Press.

Breen, Richard and Walter Müller eds. 2020a. Education and Intergenerational Social Mobility in Europe and the United States. Stanford: Stanford University Press.

Breen, Richard and Walter Müller. 2020b. "Social Mobility in the Twentieth Century in Europe and the United States". In Education and Intergenerational Social Mobility in Europe and the United States, edited by Richard Breen and Walter Müller. Stanford: Stanford University Press.

Breen, Richard, Ruud Luijkx, Walter Müller and Reinhard Pollak. 2009. "Nonpersistent Inequality in Educational Attainment: Evidence from Eight European Countries". American Journal of Sociology 114: 1475-1521.

Breen, Richard, Ruud Luijkx, Walter Müller and Reinhard Pollak. 2010. "Long-Term Trends in Educational Inequality in Europe: Class Inequalities and Gender Differences". European Sociological Review, 26: 31-48.

Brighouse, Harry and Adam Swift. 2014. Family Values. Princeton: Princeton University Press.

Bukodi, Erzsébet. 2017. "Cumulative Inequalities over the Life-Course: Life-Long Learning and Social Mobility in Britain". Journal of Social Policy 46: 367-404.

Bukodi, Erzsébet and John Goldthorpe. 2010. "Market versus Meritocracy: Hungary as a Critical Case". European Sociological Review, 26: 655-74.

Bukodi, Erzsébet and Peter Robert. 2011. "Education and Labor Market in Transition: the Case of Hungary." In Making the Transition: Education and Labor Market Entry in Central and Eastern Europe, edited by Irene Kogan et al. Stanford: Stanford University Press.

Bukodi, Erzsébet and John Goldthorpe. 2013. "Decomposing Social Origins: The Effects of Parents' Class, Status and Education on the Educational Attainment of their Children". European Sociological Review, 29: 1024-39.

Bukodi, Erzsébet and John Goldthorpe. 2016. "Educational Attainment - Relative or Absolute - as a Mediator of Intergenerational Class Mobility in Britain". Research in Social Stratification and Mobility, 43: 5-15.

Bukodi, Erzsébet and John Goldthorpe. 2019. Social Mobility and Education in Britain: Research, Politics and Policy. Cambridge: Cambridge University Press.

Bukodi, Erzsébet and John Goldthorpe. 2021a."Desigualidad social y movilidad social: Una relación inversa?" In Perspectivas y fronteras en el Estudio de la Desigualidad Social: Movilidad Social y Clases Sociales en Tiempos de Cambio, edited by Olga Salido and Sandra Fachelli.

Bukodi, Erzsébet and John Goldthorpe. 2021b. "'Primary' Factors in Intergenerational Class Mobility in Europe: Results from the Application of a Topological Model". European Sociological Review, 37: 1-17. 
Bukodi, Erzsébet and Marii Paskov. 2020. "Intergenerational Class Mobility among Men and Women in Europe: Gender Differences or Gender Similarities". European Sociological Review, 36: 495-512.

Bukodi, Erzsébet, Robert Erikson and John Goldthorpe. 2014. "The Effects of Social Origins and Cognitive Ability on Educational Attainment: Evidence from Britain and Sweden". Acta Sociologica, 57: 293-310.

Bukodi, Erzsébet, Mollie Bourne and Bastian Betthäuser. 2017. "Wastage of Talent? Social Origins, Cognitive Ability and Educational Attainment in Britain". Advances in Life Course Research, 34: 34-42.

Bukodi, Erzsébet, Marii Paskov and Brian Nolan. 2020. "Intergenerational Class Mobility in Europe: A New Account". Social Forces, 98: 941-972.

Bukodi, Erzsébet, John Goldthorpe and Yizhang Zhao. 2021. "Primary and Secondary Effects of Social Origins on Educational Attainment: New Findings for England". British Journal of Sociology, doi.org/10.1111/1468-4446.12845.

Bukodi, Erzsébet, John Goldthorpe, Brendan Halpin and Louise Waller. 2016. "Is Education Now Class Destiny? Class Histories across Three British Birth Cohort Studies", European Sociological Review, 32:835-49.

Buscha, Franz and Patrick Sturgis. 2017. "Declining Social Mobility? Evidence from Five Linked Censuses in England and Wales, 1971-2011". British Journal of Sociology, 67: 1-32.

Chan, Tak-Wing. 2018. "Social Mobility and the Well-Being of Individuals". British Journal of Sociology, 69: 183-206.

Clark, Colin. 1957. The Conditions of Economic Progress. London: Macmillan.

Craft, Nicholas and Gianni Toniolo. 2012. Economic Growth in Europe since 1945. Cambridge: Cambridge University Press.

Dotti Sani, Giulia and Judith Treas. 2016. "Educational Gradients in Parents' Child-Care Time across Countries, 1965-2012". Journal of Marriage and the Family, 78: 1083-96.

Erikson, Robert and John Goldthorpe. 1985. "Are American Rates of Social Mobility Exceptionally High?" European Sociological Review, 1: 1-22.

Erikson, Robert and John Goldthorpe. The Constant Flux: A Study of Class Mobility in Industrial Societies. Oxford: Clarendon Press.

Erikson, Robert, John Goldthorpe and Lucienne Portocarero. 1979. "Intergenerational Class Mobility in Three Western European Societies". British Journal of Sociology, 33: 415-41.

Erola, Jani. 2009. "Social Mobility and Education of Finnish Cohorts Born 1936-75: Succeeding while Failing in Equality of Opportunity", Acta Sociologica, 52: 307-27.

Featherman, David, Frank Jones and Robert Hauser. 1975. "Assumptions of Social Mobility Research in the US: the Case of Occupational Status". Social Science Research, 4: 329-60. 
Ganzeboom, Harry and Ruud Luijkx. 2004a. "Recent Trends in Intergenerational Occupational Class Reproduction in the Netherlands". In Social Mobility in Europe, edited by Richard Breen. Oxford: Oxford University Press.

Ganzeboom, Harry and Ruud Luijkx. 2004b. "More Recent Trends in Intergenerational Occupational Class Reproduction in the Netherlands 1970-2004. Netherlands Journal of Social Science, 40: 114-42.

Ganzeboom, Harry, Ruud Luijkx and Donald Treiman. 1989. "Intergenerational Class Mobility in Comparative Perspective". Research in Social Stratification and Mobility, 8: 3-84.

Gerber, Theodore. 2018. "Stalled Social Mobility in Post-Soviet Russia", Current History, October.

Gerber, Theodore and Hout, Michael. 2004. "Tightening Up: Declining Class Mobility during Russia's Market Transition". American Sociological Review, 69: 677-703.

Girod, Roger. 1971. Mobilité sociale. Geneva: Droz.

Goldthorpe, John. 2005. "Progress in Sociology: the Case of Social Mobility Research". In Analyzing Inequality, edited by Stefan Svallfors. Stanford: Stanford University Press.

Goldthorpe, John. 2007. On Sociology, 2 vols. Stanford: Stanford University Press.

Goldthorpe, John. 2014. "The Role of Education in Intergenerational Social Mobility: Problems from Empirical Work in Sociology and some Theoretical Pointers from Economics". Rationality and Society, 26: 265-89.

Goldthorpe, John. 2016. Sociology as a Population Science. Cambridge: Cambridge University Press.

Goldthorpe, John and Michelle Jackson. 2008. "Education-Based Meritocracy: The Barriers to its Realisation". In Social Class: How does it Work? Edited by Annette Lareau and Dalton Conley. New York: Russell Sage Foundation.

Grätz, Michael and Øyvind Wiborg. 2020. "Reinforcing the Top or Compensating the Bottom? Family Background and Academic Performance in Germany, Norway and the United States". European Sociological Review doi.org/10.1093/esr/jcz069.

Grusky, David. 2016. "Social Mobility and the Commodification of Opportunity". Le Frak Forum, Department of Political Science, Michigan State University.

Grusky, David and Robert Hauser. 1984. "Comparative Social Mobility Revisited: Models of Convergence and Divergence in 16 Countries". American Sociological Review, 49: 19-38.

Grusky, David, Peter A. Hall and Hazel Rose Markus. 2019. "The Rise of Opportunity Markets: How did it Happen \& What can we Do? Daedalus, 148: 19-45.

Gugushvili, Alexi, Erzsébet Bukodi and John Goldthorpe. 2017. "The Direct Effect of Social Origins on Social Mobility Chances: 'Glass Floors' and 'Glass Ceilings' in Britain". European Sociological Review, 33: 305-16.

Hauser, Robert. 1978. "A Structural Model of the Mobility Table". Social Forces, 56: 919-53. 
Hertl, Florian and Fabian Pfeffer. 2020. "The Land of Opportunity? Trends in Social Mobility and Education in the United States". In Education and Intergenerational Mobility in Europe and the United States, edited by Richard Breen and Walter Müller. Stanford: Stanford University Press.

Hirsch, Fred. 1976. Social Limits to Growth. Cambridge, Mass.: Harvard University Press.

Hout, Michael. 1983. Mobility Tables. Thousand Oaks: Sage.

Hout, Michael. 1984. "Status, Autonomy, and Training in Occupational Mobility". American Journal of Sociology, 89: 1379-409.

Hout, Michael. 2018. "Americans' Occupational Status Reflects the Status of Both of their Parents", Proceedings of the National Academy of Sciences, 115: 9527-9532.

Hout, Michael and Thomas Di Prete. 2006. "What We Have Learned: RC28's Contributions to Knowledge about Social Stratification". Research in Social Stratification and Mobility, 24: 1-20.

Ishida, Hiroshi, Walter Müller and John Ridge. 1995. "Class Origin, Class Destination, and Education: A Cross-National Study of Industrial Nations". American Journal of Sociology, 101: 145-93.

Jackson, Michelle and Geoffrey Evans. 2017. "Rebuilding Walls: Market Transition and Social Mobility in the Post-Socialist Societies of Europe". Sociological Science, 4: 54-79.

Jackson, Michelle, John Goldthorpe and Colin Mills. 2005. "Education, Employers and Class Mobility". Research in Social Stratification and Mobility, 23: 3-33.

Jones, Frank. 1969. "Social Mobility and Industrial Society: A Thesis Re-Examined". Sociological Quarterly, 10: 292-305.

Jones, Frank. 1992. "Common Social Fluidity: a Comment on Recent Criticism". European Sociological Review, 8: 233-7.

Jungblut, Jens. 2016. "Partisan Politics in Higher Education Policy: How does the Left-Right Divide of Political Parties Matter in Higher Education Policy in Western Europe?" In Higher Education in Societies, edited by Gaële Goastellac and France Picard. Rotterdam: Sense Publishers.

Kahneman, Daniel. 2011. Thinking Fast and Slow. London: Allen Lane.

Keller, Tamás and Péter Róbert. 2016. "Inequality in Educational Returns in Hungary". In Education, Occupation and Social Origin, edited by Fabrizio Bernardi and Gabriele Ballarino. Cheltenham: Edward Elgar.

Kerr, Clark, John Dunlop, Frederick Harbison and Charles Myers. 1960. Industrialism and Industrial Man. Cambridge, Mass. Harvard University Press.

Kuha, Jouni, Erzsébet Bukodi and John Goldthorpe. Forthcoming. "Mediation Analysis for Associations of Categorical Variables: The Role of Education in Social Class Mobility in Britain". Annals of Applied Statistics.

Kuznets, Simon. 1966. Modern Economic Growth. New Haven: Yale University Press. 
Layte, Richard and Christopher Whelan. 2004. "Class Transformation and Trends in Social Fluidity in the Republic of Ireland". In Social Mobility in Europe, edited by Richard Breen. Oxford: Oxford University Press.

Lieberson, Stanley. 1987. Making it Count. Berkeley: University of California Press.

Lipset, Martin and Hans Zetterberg. 1959. "Social Mobility in Industrial Societies". In Martin Lipset and Reinhard Bendix, Social Mobility in Industrial Society. Berkeley: University of California Press.

Long, Jason and Joseph Ferrie. 2013. "Intergenerational Occupational Mobility in Great Britain and the United States since 1850”. American Economic Review, 103: 1109-1137.

Lucas, Samuel. 2001. "Effectively Maintained Inequality: Education Transitions, Track Mobility, and Social Background Effects". American Journal of Sociology, 106: 1642-90.

Mach, Bogdan. 2004. "Intergenerational Mobility in Poland: 1972-88-94". In Social Mobility in Europe, edited by Richard Breen. Oxford: Oxford University Press.

Markovits, Daniel. 2019. The Meritocracy Trap. New York: Penguin Press.

Mateju, Petr, Blanka Rehakova and Natalie Simonova. 2003. "Transition to University under Communism and after its Demise: the Role of Socioeconomic Background in the Transition between Secondary and Tertiary Education in the Czech Republic, 1948-1998". Czech Sociological Review, 39: 301-24.

Merton, Robert. 1987. "Three Fragments from a Sociologist's Notebook: Establishing the Phenomenon, Specified Ignorance and Strategic Research Materials". Annual Review of Sociology, 13: 1-28.

Miller, Michael. 1960. "Comparative Social Mobility". Current Sociology, 9.

Mitnik, Pablo, Erin Cumberworth and David Grusky. 2016. "Social Mobility in a High-Inequality Regime". Annals of the American Academy of Political and Social Science, 663: 140-84.

Parsons, Talcott. 1960. Structure and Process in Modern Societies. Glencoe: Free Press.

Präg, Patrick and Lindsay Richards. 2019. "Intergenerational Social Mobility and Allostatic Load in Great Britain". Journal of Epidemiology and Community Health, 73: 100-05.

Präg, Patrick and Alexi Gugushvili. 2020. "Intergenerational Social Mobility and Self-Rated Health in Europe", SocArXiv. August 15. doi:10.31235/osf.io/5tk4z.

Reeves, Richard. 2017. Dream Hoarders. Washington DC: Brookings Institution.

Rose, David and Eric Harrison. 2010. Social Class in Europe: An Introduction to the European SocioEconomic Classification. London: Routledge.

Rostow, Walter. 1960. The Stages of Economic Growth: A Non-Communist Manifesto. Cambridge: Cambridge University Press.

Saar, Ellu. 2010. "Changes in Intergenerational Mobility and Educational Inequality in Estonia: Comparative Analyses of Cohorts Born between 1930 and 1974". European Sociological Review, 26: 367-83. 
Shavit, Yossi and Hans-Peter Blossfeld. 1993. Persistent Inequality: Changing Educational Attainment in Thirteen Countries. Boulder: Westview Press.

Simkus, Arthur. 1981. "Changes in Occupational Inheritance under Socialism: Hungary 1930-73". Research in Social Stratification and Mobility, 1: 171-203.

Simkus, Arthur and Rudolf Andorka. 1982. "Inequalities in Education in Hungary 1923-1973". American Sociological Review, 47: 740-51.

Singelmann, Joachim. 1978. From Agriculture to Services. Beverly Hills: Sage.

Solga, Heike. 2006. "The Rise of Meritocracy? Class Mobility in East Germany Before and After 1989". In After the Fall of the Wall: Life Courses in the Transformation of East Germany, edited by Martin Diewald, Anne Goedicke and Karl Mayer.

Sorokin, Pitirim. 1927/1959. Social and Cultural Mobility. Glencoe: Free Press.

Sturgis, Patrick and Franz Buscha. 2015, "Increasing Inter-Generational Social Mobility: Is Educational Expansion the Answer?" British Journal of Sociology, 66: 512-33.

Swift, Adam. 2204. "Would Perfect Mobility be Perfect?" European Sociological Review, 20: 1-11.

Szelényi, Szonja. 1998. Equality by Design: the Grand Experiment in Destratification in Socialist Hungary. Stanford: Stanford University Press.

Thurow, Lester. 1976. Generating Inequality. London: Macmillan.

Thurow, Lester. 1983. Dangerous Currents: the State of Economics. New York: Vintage.

Titma, Mikk, Nancy Tuma and Kadi Roosma. 2003. "Education as a Factor in Intergenerational Mobility in Soviet Society". European Sociological Review, 19: 281-97.

Torche, Florencia. 2015. "Analyses of Intergenerational Mobility: An Interdisciplinary Review". Annals of the American Academy of Political and Social Science, 657: 37-62.

Treiman, Donald. 1970. "Industrialization and Social Stratification". In Social Stratification: Research and Theory for the 1970s, edited by Edward Laumann. Indianapolis: Bobbs-Merril.

Triventi, Moris, Nazareno Panichella, Gabriele Ballarino, Carlo Barone and Fabrizio Bernardi. 2016. "Education as a Positional Good: Indications for Social Inequalities in Educational Attainment in Italy". Research in Social Stratification and Mobility, 43: 39-52.

Vallet, Louis-André. 2014. "Mobilité observée et fluidité sociale en France de 1977 à 2003" Idées economiques et sociales, 176: 6-17.

Vallet, Louis-André. 2020. "Intergenerational Mobility and Social Fluidity in France over Birth Cohorts and Age: the Role of Education". In Education and Intergenerational Mobility in Europe and the United States, edited by Richard Breen and Walter Müller. Stanford: Stanford University Press.

Veblen, Thorstein. 1899. The Theory of the Leisure Class. New York: Macmillan. 
Whelan, Christopher and Richard Layte. 2006. "Economic Boom and Social Mobility: the Irish Experience". Research in Social Stratification and Mobility, 24: 193-208.

Wong, Raymond. 1994. "Postwar Mobility Trends in Advanced Industrial Societies". Research in Social Stratification and Mobility, 13: 121-44. 